\title{
Effective Removal of Nitrates Ions from Aqueous Solution Using New Clay as Potential Low-Cost Adsorbent
}

\author{
Mahmoud El Ouardi*, Samir Qourzal, Said Alahiane, Ali Assabbane, Jamaa Douch \\ Photocatalysis and Environment Team, Physical Chemistry Laboratory, Department of Chemistry, \\ Faculty of Science, Ibn Zohr University, Agadir, Morocco \\ Email: *elouardi.mahmoud.@gmail.com
}

Received 19 September 2015; accepted 30 November 2015; published 3 December 2015

Copyright (C) 2015 by authors and Scientific Research Publishing Inc.

This work is licensed under the Creative Commons Attribution International License (CC BY). http://creativecommons.org/licenses/by/4.0/

c) (i) Open Access

\begin{abstract}
In the present study, we investigated the performance of clay mineral originated from a dam situated in Morocco (Agadir city), as natural, low-cost, alternative and eco-friendly adsorbent for removal of nitrates ions from aqueous solution within a batch process. The clay was characterized by X-ray diffraction, Scanning Electron Microscopy (SEM), Dispersive Energy of Spectroscopy (EDS), Fourier Transform Infrared (FTIR) and surface area analysis (BET). The effects of various experimental parameters are examined such as contact time, initial concentration of pollutant, adsorbent mass and solution $\mathrm{pH}$. The removal of nitrate was $71.89 \%$ at natural $\mathrm{pH}(\mathrm{pH}=5.1)$ using $1 \mathrm{~g} / \mathrm{l}$ of adsorbent in $500 \mathrm{ml}$ of nitrate solution having initial concentration of $300 \mathrm{mg} / \mathrm{l}$ (effect of contact time). Adsorption kinetic study revealed that the adsorption process followed first order kinetic. Theoretical correlation of the experimental equilibrium adsorption data for the NitrateNew Clay system was properly explained by the Langmuir isotherm model. The maximum adsorption capacity was $Q_{\mathrm{m}, \exp }=244.06 \mathrm{mg} / \mathrm{g}$ at $20^{\circ} \mathrm{C}$ and at natural $\mathrm{pH}$ (with $Q_{\mathrm{m} \text {, cal }}=250 \mathrm{mg} / \mathrm{g}$ ). An increase in adsorbent dosage increased the percent removal of nitrate, $R=1 \mathrm{~g} / \mathrm{l}$ was considered as optimum dose and was used for further study. The $\mathrm{pH}$ heavily affected the adsorption capacity, and the percentage removal was found to decrease with increase in $\mathrm{pH}$. The obtained results indicated that this New Clay (NC) was very good adsorbent for $\mathrm{NO}_{3}^{-}$, interesting alternative material with respect to more costly adsorbent used, and could be used as a highly efficient adsorbent for the separation of nitrate from drinking or waste water.
\end{abstract}

\section{Keywords}

New Clay, Adsorption Capacity, Isotherms, Nitrate Removal, Waste Water

\footnotetext{
${ }^{*}$ Corresponding author.
}

How to cite this paper: El Ouardi, M., Qourzal, S., Alahiane, S., Assabbane, A. add Douch, J. (2015) Effective Removal of Nitrates lons from Aqueous Solution Using New Clay as Potential Low-Cost Adsorbent. Journal of Encapsulation and Adsorption Sciences, 5, 178-190. http://dx.doi.org/10.4236/jeas.2015.54015 


\section{Introduction}

Nitrate contamination in groundwater has become an ever increasing and serious environmental threat since 1970s [1]. The excessive application of fertilizers in agriculture causes the infiltration of large quantities of this ion into underground and surface water [2]. Nitrate, due to its high water solubility [3], is possibly the most widespread groundwater contaminant in the world, imposing a serious threat to drinking water supplies and promoting eutrophication [4] [5]. Elevated levels of nitrate in drinking water can cause many health problems such as gastric cancer, which results from the reduction of nitrate to nitrosamines in the stomach [6]. In addition, methemoglobinemia or blue baby syndrome, a serious health risk, occurs when nitrate is converted to nitrite, which then reacts with the hemoglobin to cause blueness of the skin of newborn infants [7]. After ingestion of plants or water high in $\mathrm{NO}_{3}^{-}$, acute poisoning may occur within 30 mins to 4 hrs in cattle. Thus, the problem occurs very quickly and often the cattle are observed to be normal one day and dead the next day [8]. Ward et al. [9] reviewed the epidemiologic evidence for the linkages between drinking water $\mathrm{NO}_{3}^{-}$and the risk of specific cancers, adverse reproductive outcomes, and other health outcomes in the context of the current regulatory limit for nitrate in drinking water. Nitrate contaminated water supplies have also been linked to outbreaks of infectious diseases in humans [10]. Literature survey reveals that $\mathrm{NO}_{3}^{-}$ion also causes diabetes and is a precursor of carcinogen [11] [12]. US Environmental Protection Agency (EPA) has set the maximum contamination level as $44 \mathrm{mg} / \mathrm{l}$ of $\mathrm{NO}_{3}^{-}$[13].

Therefore, numerous techniques for the removal of nitrate from water samples have been reported. These include biological de-nitrification [14], chemical reduction [15], reverse osmosis, electrodialysis [16], and ion exchange [17], but adsorption has been shown to be an economical and effective alternative for removing ions from water. Adsorption, in general, is the process of collecting soluble substances that are in solution on a suitable interface. Clays have been widely used as adsorbents for pollution control due to their high uptake ability, non-toxicity and large potential for ion exchange [18].

The main aim of our study is to determine the adsorption capacity of locally available natural clay materials originated from a dam situated in Morocco (Agadir city) and to remove nitrate from its aqueous solution. Hence, the effect of various parameters on the adsorption process has been investigated: contact time, solution $\mathrm{pH}$, and mass of adsorbent and nitrate concentration. The results are presented and discussed in this study. It is interesting to note that the adsorption of cationic and anionic dyes on this support is examined in our laboratory [19].

\section{Materials and Methods}

\subsection{Materials}

Potassium nitrate used in the present study was of analytical grade and was obtained from Sigma-Aldrich. 1000 $\mathrm{mg} / \mathrm{l}$ stock solution of nitrate was prepared. The required concentration of nitrate solution was obtained by serial dilution of the stock nitrate solution.

The untreated clay used in this work is crushed then sifted in order to get fractions $<80 \mu \mathrm{m}$. Afterwards, the support is rinsed many times with distilled water, of $\mathrm{pH}=6.5$ and of conductivity $=1.1 \mu \mathrm{S}$. After every rinse, the clay is put in a sedimentation test, and during one hour of decantation, we recover the two thirds of supernatant volume. Finally, it is placed in an oven between $110^{\circ} \mathrm{C}$ and $120^{\circ} \mathrm{C}$ during $24 \mathrm{hrs}$, before being subjected to different adsorptions.

\subsection{Nitrate Adsorption Studies}

The ability of our new clay mineral (NC) to adsorb nitrate ion was tested at different conditions (Table 1) using a series of batch tests. A number of parameters such as reaction time, concentration of nitrate, adsorbent dose and $\mathrm{pH}$, affecting the removal of nitrate ion have been varied widely in order to optimize the removal process. The experiments were carried out in $200 \mathrm{ml}$ conical flasks by mixing a pre-weighted amount of adsorbent with $100 \mathrm{ml}$ of nitrate solution (300 mg/l). The solution was agitated at $400 \mathrm{rpm}$ on a stirrer during $180 \mathrm{~min}$ (adsorption equilibrium), at natural $\mathrm{pH}(\mathrm{pH}=5.1)$, at $\mathrm{T}=20^{\circ} \mathrm{C}$ and with $\mathrm{R}=1 \mathrm{~g} / \mathrm{l}$. All samples were filtered (through a $0.45 \mu \mathrm{m}$ Millipore) prior to analysis using disposable syringes in order to minimize interference of the particles fines with the analysis. The nitrate concentrations in liquid phase were determined by a spectrophotometric method (spectrophotometer type JASCO V-630, $\lambda_{\max }=410 \mathrm{~nm}$ ) based on colourimetric determination using chromotropic acid and sulfuric acid (99\%). This method is highly selective, very sensitive, and can be quickly and 
Table 1. Experimental conditions.

\begin{tabular}{cccccc}
\hline & Solution $\mathrm{pH}$ & $\begin{array}{c}\text { NC } \\
\text { Dose }(\mathrm{g} / \mathrm{l})\end{array}$ & $\begin{array}{c}\text { Concentrations } \\
(\mathrm{mg} / \mathrm{l})\end{array}$ & $\begin{array}{c}\text { Mixing } \\
\text { Time }(\mathrm{min})\end{array}$ & Volume (ml) \\
\cline { 2 - 6 } & $\mathrm{pH}_{\text {natural }}=5.1$ & 1 & 300 & 300 & 500 \\
\hline $\begin{array}{c}\text { Effect of } \\
\text { contact time } \\
\text { Effect of initial } \\
\text { solution } \mathrm{pH} \\
\begin{array}{c}\text { Effect of } \\
\text { adsorbent dose }\end{array}\end{array}$ & $2-10$ & 1 & 300 & 180 & 100 \\
$\begin{array}{c}\text { Effect of initial nitrate } \\
\text { concentration }\end{array}$ & $\mathrm{pH}_{\text {natural }}=5.1$ & $0.2-2$ & 300 & 180 & 100 \\
\hline
\end{tabular}

easily applied [20] [21]. On calculating the difference between the initial and final concentrations of nitrate in aqueous phase, the amount of adsorbed nitrate at equilibrium $\left(Q_{e}\right)$ was calculated (Equation $\left.(1)\right)$ and the percentage of nitrate removed was also determined (Equation (2)):

$$
\begin{gathered}
\qquad Q_{e}=\left(C_{0}-C_{e q}\right) / R \\
\text { Percentage of nitrate removed }(\%)=\frac{\left(C_{0}-C_{e q}\right)}{C_{0}} \times 100
\end{gathered}
$$

with:

$Q_{e}$ : Quantity of nitrate adsorbed per gram of adsorbent (mg/g);

$C_{0}$ : Initial concentration (mg/1);

$C_{e}$ : Equilibrium concentration (mg/l);

$R$ : Mass of adsorbent per liter of aqueous solution (g/1).

\subsection{Characterization of the Adsorbent}

X-ray powder diffraction pattern was obtained using the diffractometer XPERT-PRO type PW3064, with copper anticathode. The spectrum of XRD shows that the untreated clay contains a large amount of the Kaolinite (38\%) and Illite (24\%) followed by Quartz (20\%) and Calcite (18\%) (Figure 1), the amounts of the phases were calculated by X'PERT Highscore plus software. The BET (Brunauer-Emmett-Teller) surface area of clay was measured by nitrogen $\left(\mathrm{N}_{2}\right)$ adsorption-desorption isotherms at $(77 \mathrm{~K})$ using an automated gas sorption system (Micromeritics, Quantachrome instrument). The determined surface area is equal to $53.47 \mathrm{~m}^{2} / \mathrm{g}$.

The morphology of the clay powder particles was observed by scanning electron microscopy (SEM, using Zeiss Ultra Plus) with a coupled energy dispersive spectroscopy (EDS), at $5 \mathrm{kV}$, after gold coating. The morphological aspects of the clay particles are outlined in Figure 2. The porosity of the surface is clearly visible. The scanning electron micrograph shows the typical regular shapes of the clay particles. The powder is rich in porous and microporous particles that formed noticeable cage-like cavities. These cavities provide suitable binding sites for nitrates ions. On the basis of this fact, it can be concluded that our clay presents an adequate morphology for nitrate adsorption. The chemical compositions (Table 2) have been checked using energy dispersive spectroscopy (EDS) (Figure 3). The point of zero charge (PZC) of our clay was determined by the solid addition method [22]. The $\mathrm{pH}_{\mathrm{PZC}}$ of $\mathrm{NC}$ was determined to be 5.6.

In order to determine the surface functional groups, the Fourier Transform Infrared (FTIR) spectrum of the NC was obtained by using a Bruker Vertex 70 spectrophotometer, at a resolution of $4 \mathrm{~cm}^{-1}$ and averaging over 20 scans, in the range $400-4000 \mathrm{~cm}^{-1}$.

The FTIR spectrum of our clay was depicted in Figure 4. The bands at $3695.7 \mathrm{~cm}^{-1}$ and $3620.3 \mathrm{~cm}^{-1}$ correspond to the inner $\mathrm{OH}$ stretching vibration, while that at $3435.5 \mathrm{~cm}^{-1}$ represents the outer surface $\mathrm{OH}$ stretching vibration. Si-O bending vibration was observed at $1114.2 \mathrm{~cm}^{-1}, 1031.7 \mathrm{~cm}^{-1}$ and $1008.5 \mathrm{~cm}^{-1}$, while the stretching vibration was observed at $698.5 \mathrm{~cm}^{-1}$ and $796.1 \mathrm{~cm}^{-1}$. Absorption band at $913.0 \mathrm{~cm}^{-1}$ correspond to the Al-O bending vibration and peak intensities recorded at $537.7 \mathrm{~cm}^{-1}, 469.7 \mathrm{~cm}^{-1}$ and $430.2 \mathrm{~cm}^{-1}$ are due to Al-OSi skeletal vibrations [23] [24]. 


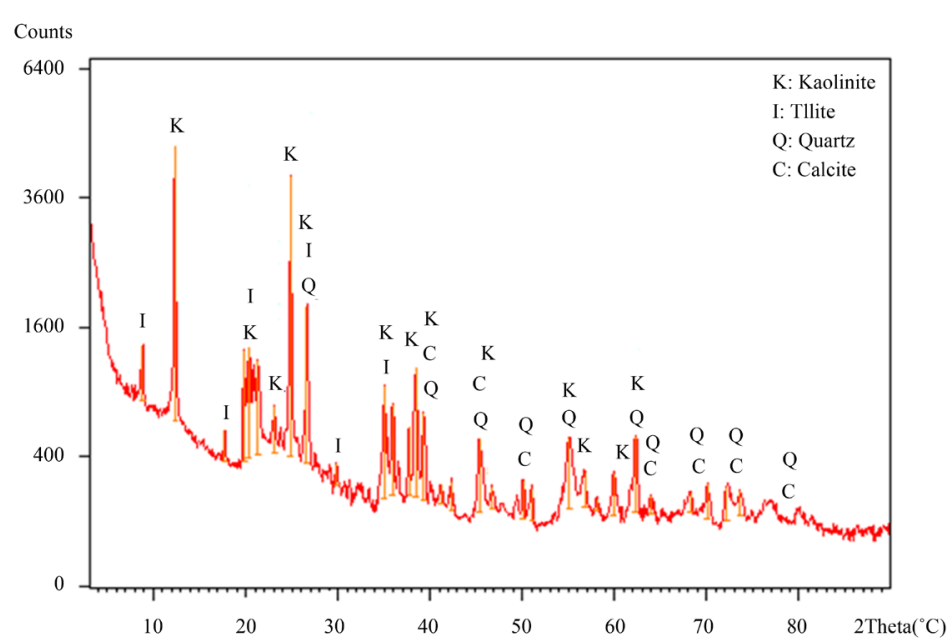

Figure 1. X-ray diffraction pattern of the NC.

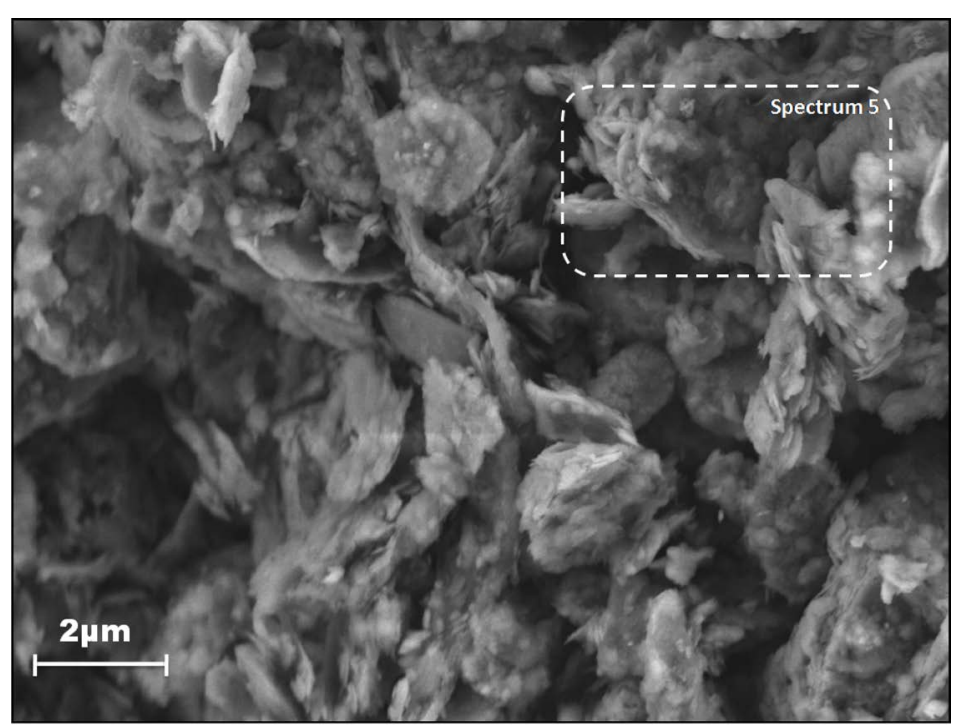

Figure 2. SEM micrograph of the NC particles.

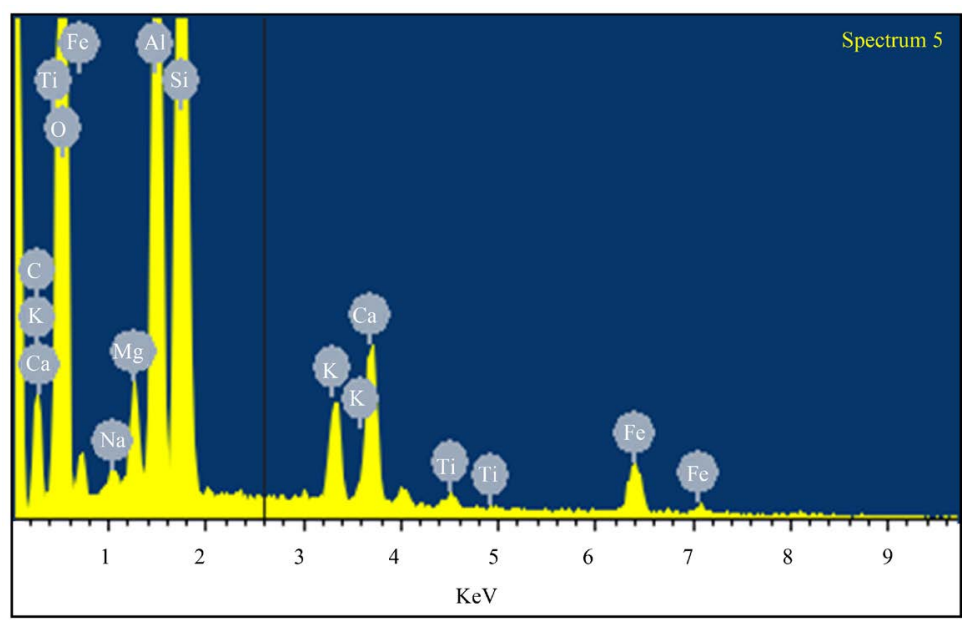

Figure 3. Dispersive energy spectrum (EDS) of the NC. 


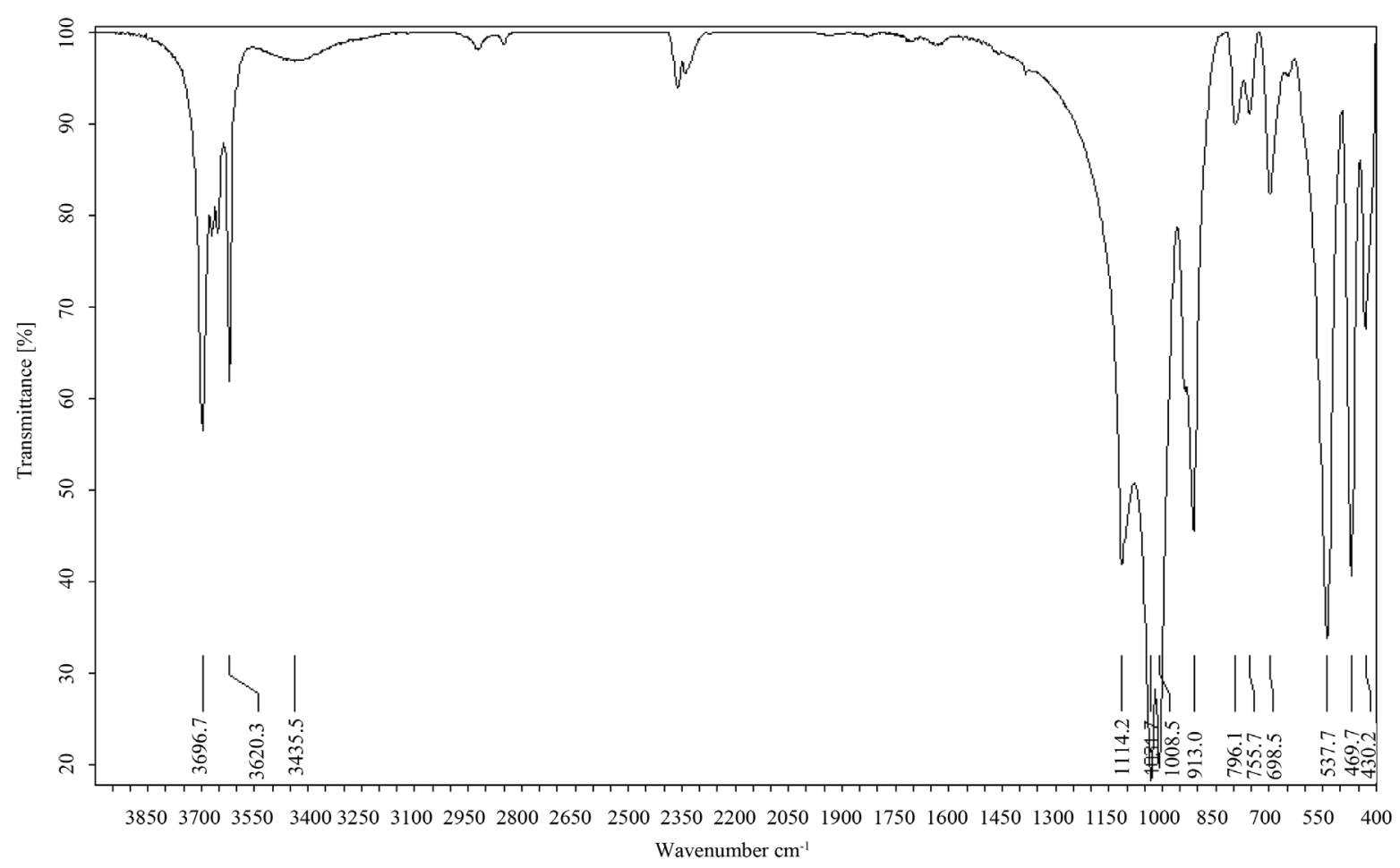

Figure 4. FTIR spectra of the NC.

Table 2. Atomic and mass percentage of the NC constituents.

\begin{tabular}{cccccccccccc}
\hline Elements & $\mathrm{O}$ & $\mathrm{C}$ & $\mathrm{Na}$ & $\mathrm{Mg}$ & $\mathrm{Al}$ & $\mathrm{Si}$ & $\mathrm{K}$ & $\mathrm{Ca}$ & $\mathrm{Ti}$ & $\mathrm{Fe}$ \\
\hline \% Atomic & 67.71 & 3.27 & 0.26 & 1.03 & 7.20 & 14.82 & 1.36 & 2.29 & 0.26 & 1.79 \\
\% Mass & 53.58 & 1.94 & 0.30 & 1.24 & 9.61 & 20.59 & 2.63 & 4.53 & 0.62 & 4.94 \\
\hline
\end{tabular}

\section{Results and Discussion}

\subsection{Effect of Contact Time}

Adsorption kinetic is an important characteristic for evaluating the efficiency of adsorption. The kinetic behavior of this process was studied at natural pH (Table 1). It appears from Figure 5 that the kinetic of nitrate adsorption consists of two phases, an initial rapid phase when the process is very fast and a second slower phase when it reaches equilibrium. The initial high rate of nitrate uptake is probably due to the greater availability of binding sites near the surface of the clay [25]. The kinetic study indicates that the adsorption equilibrium state is reached after a contact time of $180 \mathrm{~min}$ with $Q_{e}=215.69 \mathrm{mg} / \mathrm{g}$ since no change in the adsorbed amount is detected afterward.

\subsection{Adsorption Kinetics}

The kinetics of adsorption data was processed to understand the dynamics of adsorption process in terms of the order of rate constant. Two kinetic models were applied to the adsorption kinetic data in order to investigate the behavior of adsorption process of nitrates onto our clay. These models are the pseudo-first-order and pseudo-second-order models.

The pseudo-first-order equation is given by [26]:

$$
\mathrm{d} q_{t} / \mathrm{d} t=K_{1}\left(q_{e}-q_{t}\right)
$$

where $q_{e}$ and $q_{t}$ are the amounts of nitrate adsorbed (mg/g) at equilibrium and at time $t$ (min), respectively, and $k_{1}(\mathrm{l} / \mathrm{min})$ is the rate constant of first-order adsorption. 
The pseudo-second order process can be written as follows [27]:

$$
\mathrm{d} q_{t} / \mathrm{d} t=K_{2}\left(q_{e}-q_{t}\right)^{2}
$$

where $k_{2} \mathrm{~g} /(\mathrm{min} . \mathrm{mg})$ is the rate constant of second-order adsorption. The fit of these models was checked by each linear plot of $\ln \left(q_{e}-q_{t}\right)$ versus $t$ (Figure 6), $\left(t / q_{t}\right)$ versus $t$ (Figure 7). The kinetic constants and correlation coefficients of the pseudo-first-order and the pseudo-second-order models are given in Table 3. The results showed that the adsorption system followed the pseudo-first-order model, with correlation coefficient value of 0.998 which is better than the second-order-model $(0.928)$ and the calculated $q_{\mathrm{e}, \text { cal }}$ value from the model is also in good agreement with the experimental value $q_{\mathrm{e}, \text { exp }}$ (Table 3 ).

Table 3. Kinetic parameters for the adsorption of nitrates ions onto NC.

\begin{tabular}{|c|c|c|c|c|c|c|}
\hline $\begin{array}{c}q_{\mathrm{e}, \exp } \\
(\mathrm{mg} / \mathrm{g})\end{array}$ & \multicolumn{3}{|c|}{ First-order kinetic model } & \multicolumn{3}{|c|}{ Second-order kinetic model } \\
\hline \multirow[t]{2}{*}{215.69} & $\begin{array}{c}k_{1} \\
(\mathrm{l} / \mathrm{min})\end{array}$ & $\begin{array}{c}q_{\mathrm{e}, \mathrm{cal}} \\
(\mathrm{mg} / \mathrm{g})\end{array}$ & $R^{2}$ & $\begin{array}{c}k_{2} \\
(\mathrm{~g} / \mathrm{mg} \min )\end{array}$ & $\begin{array}{c}q_{\mathrm{e}, \mathrm{cal}} \\
(\mathrm{mg} / \mathrm{g})\end{array}$ & $R^{2}$ \\
\hline & 0.020 & 224.752 & 0.998 & $3.515 \times 10^{-5}$ & 333.333 & 0.928 \\
\hline
\end{tabular}

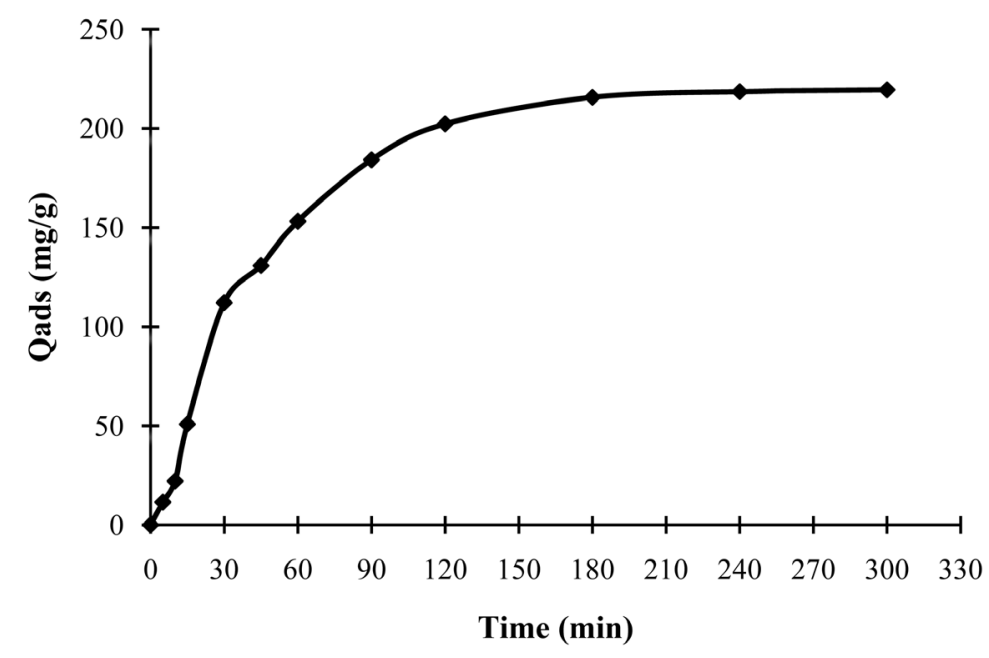

Figure 5. Effect of contact time on the adsorption of nitrates ions.

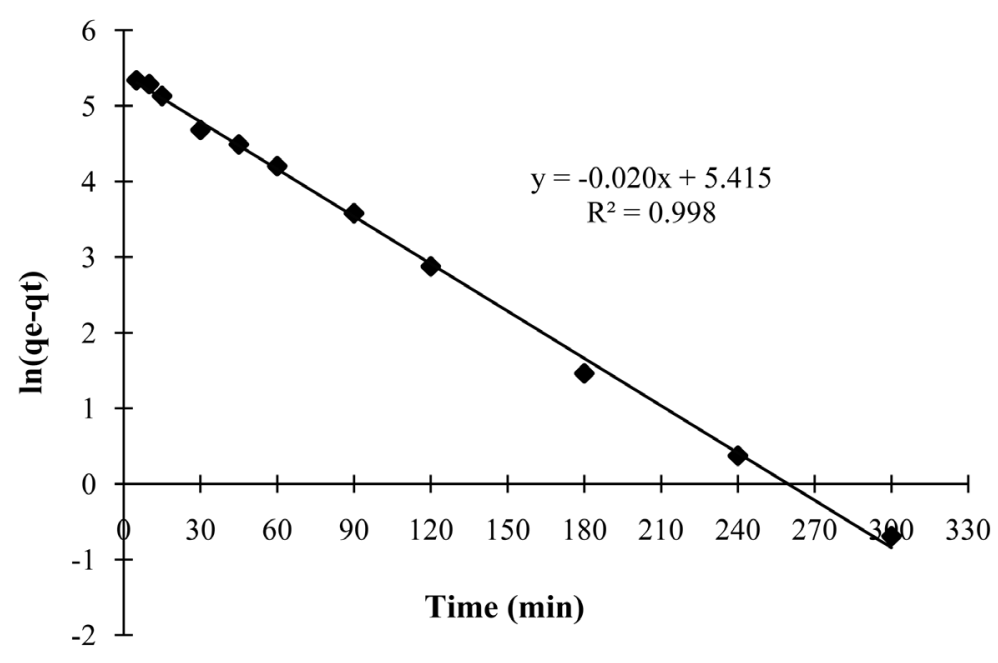

Figure 6. Pseudo-first-order kinetic plots. 


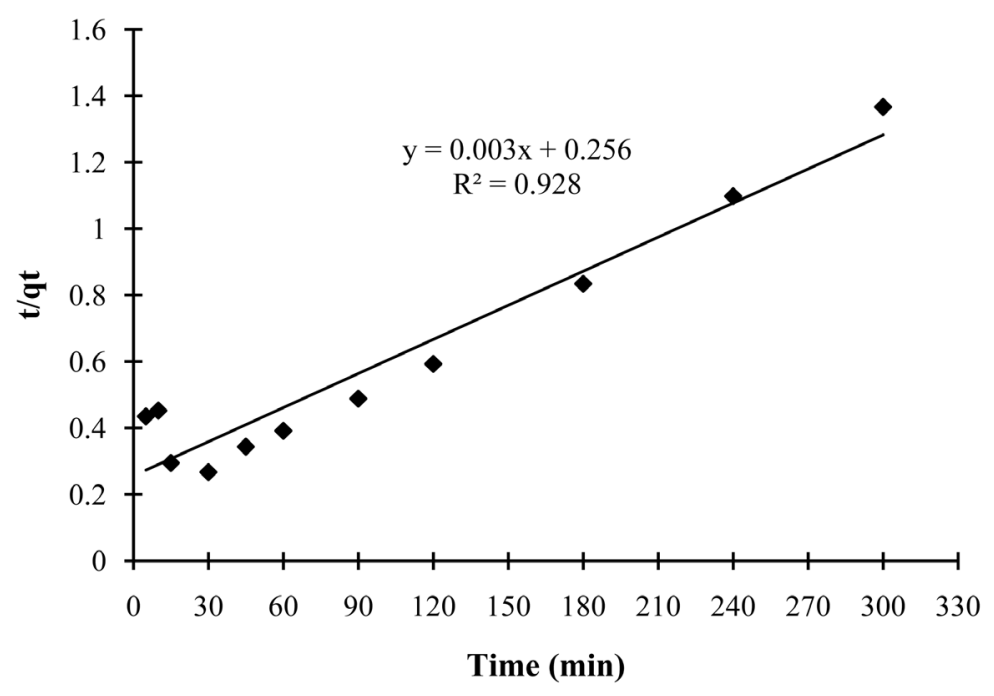

Figure 7. Pseudo-second-order kinetic plots.

\subsection{Effect of Initial Solution pH}

The effect of initial solution $\mathrm{pH}$ on nitrate removal is illustrated in Figure 8. The initial $\mathrm{pH}$ values were adjusted by adding $0.1 \mathrm{M}$ of $\mathrm{HCl}$ or $\mathrm{NaOH}$. It is evident from the figure that the percentage removal of nitrate decreased from $92.72 \%$ to $38.96 \%$ for increase in $\mathrm{pH}$ from 2 to 10 . The variation of adsorption with $\mathrm{pH}$ can be explained by the electrostatic interaction between the adsorbent and adsorbate. With increase of $\mathrm{pH}$ values, the surfaces gradually decrease in the extent of positive charging and become negative at $\mathrm{pH}$ of about 6 (the isoelectric points of clay is at $\mathrm{pH}=5.6$ ). Thus, the high adsorption capacity at low $\mathrm{pH}$ is mainly due to the strong electrostatic interaction between the positively charged sites of adsorbent (presence of $\mathrm{H}^{+}$) and the anions. However, lower sorption of the nitrates ions at alkaline $\mathrm{pH}$ could be attributed to the abundance of $\mathrm{OH}^{-}$ions which will compete with the pollutant for the same sorption sites [28].

\subsection{Effect of Adsorbent Dose}

For studying the effect of mass of adsorbent on nitrate adsorption onto our clay, experiments were performed with varying amounts of adsorbent, ranging from 0.2 to $2 \mathrm{~g} / \mathrm{l}$ (Figure 9). It is evident from the figure that the removal of nitrate increased from $9.84 \%(0.2 \mathrm{~g} / \mathrm{l})$ to $72.97 \%(1 \mathrm{~g} / \mathrm{l})$. This study revealed that the adsorption capacity of clay increased with increase in adsorbent dose up to a particular region and then reaches an equilibrium level at higher doses. However it is observed that after dosage of $1 \mathrm{~g} / \mathrm{l}$, there was no significant change in percentage removal of nitrate. This may be due to the overlapping of active sites at higher dosage. So, there was not any appreciable increase in the effective surface area resulting due to the conglomeration of adsorbent particles [29]. Thus, $1 \mathrm{~g} / \mathrm{l}$ in $100 \mathrm{ml}$ of nitrate solution was considered as an optimum dose and was used for further study.

\subsection{Effect of Initial Nitrate Concentration}

The influence of initial nitrate concentration on adsorption percentage was estimated (Figure 10). The initial concentration of nitrate solution was varied from $100 \mathrm{mg} / \mathrm{l}$ to $450 \mathrm{mg} / \mathrm{l}$ with optimum adsorbent dose $(1 \mathrm{~g} / \mathrm{l})$. The result obtained is presented in graphical form as percentage removal versus initial nitrate concentration. It is evident from the graph that the percentage removal of nitrate decreased from $97.77 \%$ to $53.40 \%$ for initial nitrate concentration of $100 \mathrm{mg} / \mathrm{l}$ to $450 \mathrm{mg} / \mathrm{l}$. It is due to the limitation of adsorption sites on the clay mineral surface [30] [31]. This can be explained as follows: with increase in the initial nitrate concentration the amount of adsorbate species in the solution increases, but the amount of adsorbent remains constant and hence the percentage removal decreases with increase in initial nitrate concentration. The higher uptake of nitrate at low concentration may be attributed to the availability of more active sites on for lesser number of adsorbate species [32]. 


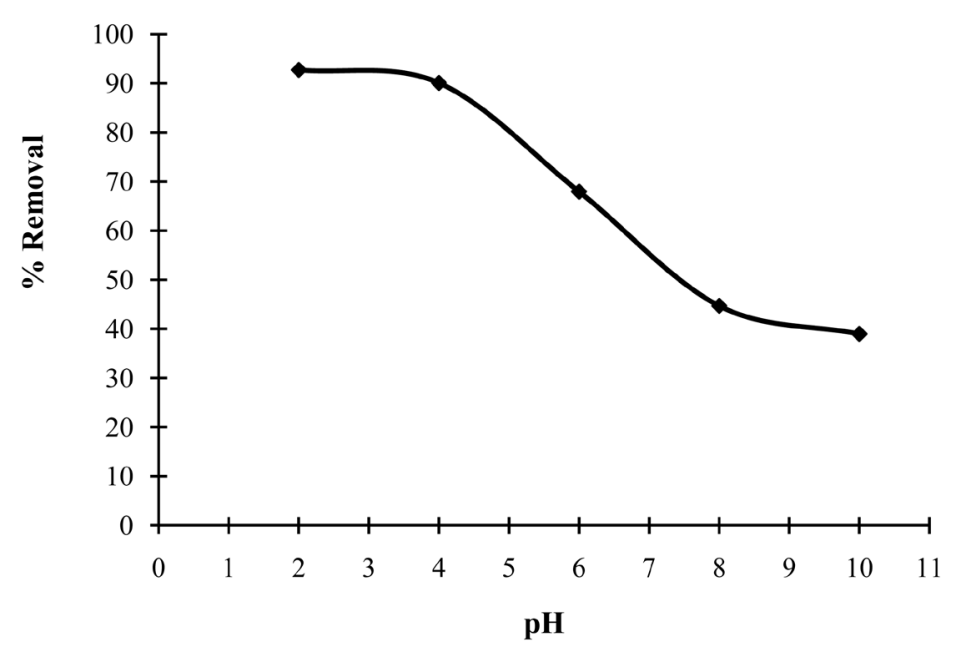

Figure 8. Influence of $\mathrm{pH}$ on the adsorption of nitrates ions.

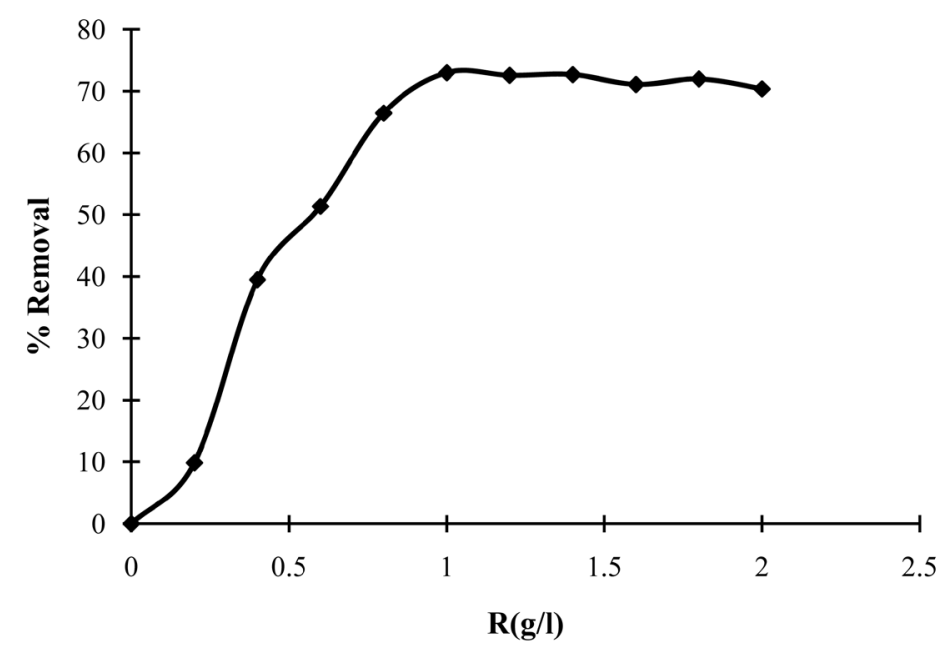

Figure 9. Effect of adsorbent dose on the adsorption of nitrates ions.

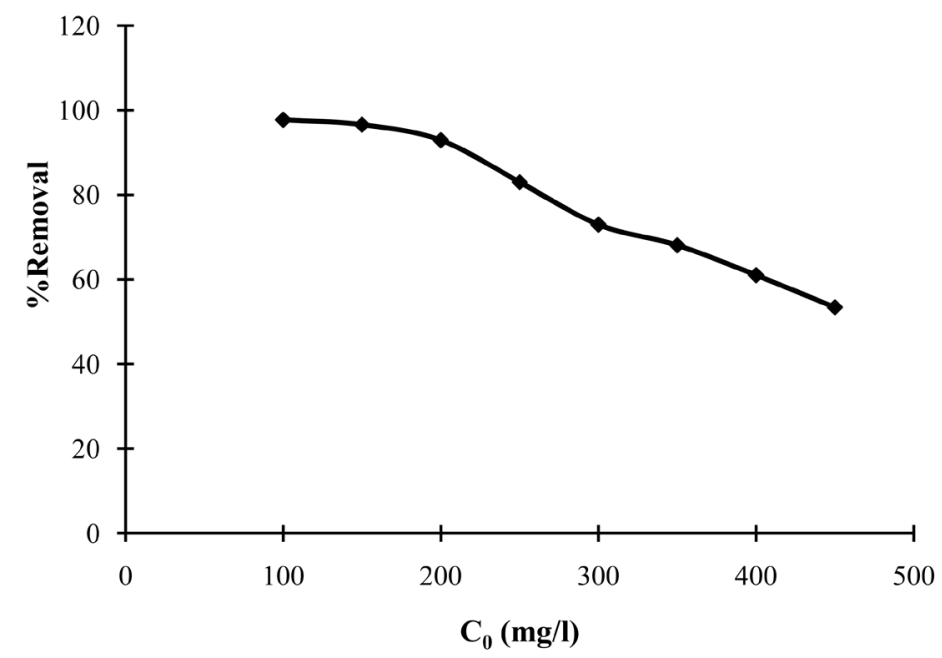

Figure 10. Influence of initial concentration on the adsorption of nitrates ions. 


\subsection{Adsorption Isotherms Studies}

Adsorption isotherms indicate distribution of adsorbate between solution and adsorbent at the equilibrium state of the adsorption process [33]. It is expressed by relating the amount of adsorbate taken up per gram of adsorbent, $Q_{e}(\mathrm{mg} / \mathrm{g})$, to the equilibrium solution concentration, Ce $(\mathrm{mg} / \mathrm{l})$, and at different concentrations of nitrates ions solutions (100, 150, 200, 250, 300, 350, 400 and $450 \mathrm{mg} / \mathrm{l}$ ), (Figure 11). Monolayer saturation is attained. The type of adsorption isotherm model is very important in order to understand the adsorption behavior for solid-liquid adsorption system [34]. In the present study, Langmuir and Freundlich models were tested to study the adsorption behavior of nitrate as these two are the most commonly used.

\subsubsection{Langmuir Isotherm}

The Langmuir isotherm is based on the assumptions that adsorption takes place at specific homogeneous sites within the adsorbent, there is no significant interaction among adsorbed species, and the adsorbent is saturated after the formation of one layer of adsorbate on the surface of adsorbent [35]. The Langmuir isotherm equation can be written as follows:

$$
Q_{e}=Q_{m} K_{L} C_{e} /\left(1+K_{L} C_{e}\right)
$$

The linearized form of Equation (5) can be written as Equation (6):

$$
C_{e} / Q_{e}=1 / K_{L} \cdot Q_{m}+C_{e} / Q_{m}
$$

where $C_{e}$ is the equilibrium concentration of the remaining solute in the solution (mg/l), $Q_{e}$ is the amount of the solute adsorbed per mass unit of adsorbent at equilibrium (mg/g), $Q_{m}$ is the amount of adsorbate per mass unit of adsorbent at complete monolayer coverage $(\mathrm{mg} / \mathrm{g})$, and $K_{L}(\mathrm{l} / \mathrm{mg})$ is a Langmuir constant. In this work, we used the linear form of Langmuir isotherm equation and therefore, a plot $1 / Q_{e}$ versus $1 / C_{e}$ should indicate a straight line. The $Q_{m}$ and $K_{L}$ values were calculated from the slopes $\left(1 / Q_{m}\right)$ and intercepts $\left(1 / K_{L} \cdot Q_{m}\right)$ of linear plots of $1 / Q_{e}$ versus $1 / C_{e}$ (Figure 12). The Langmuir isotherms parameters are given in Table 4 . The isotherm data of layered clay fits well the Langmuir equation with a correlation coefficient, $R^{2}=0.992$ and shows excellent linearity (Figure 12). The theoretical monolayer saturation capacity $Q_{\mathrm{m}, \text { cal }}$ is in good agreement with the experimental value $Q_{\mathrm{m} \text {, exp }}$ (Table 4).

One of the essential characteristics of the Langmuir model could be expressed by a dimensionless constant called equilibrium parameter, $R_{L}$ which is determined as follows [36] [37]:

$$
R_{L}=\frac{1}{1+K_{L} C_{0}}
$$

where $C_{0}$ is the initial nitrate concentration ( $\left.\mathrm{mg} / \mathrm{l}\right)$. The value of $R_{L}$ indicates the type of isotherm to be irreversible

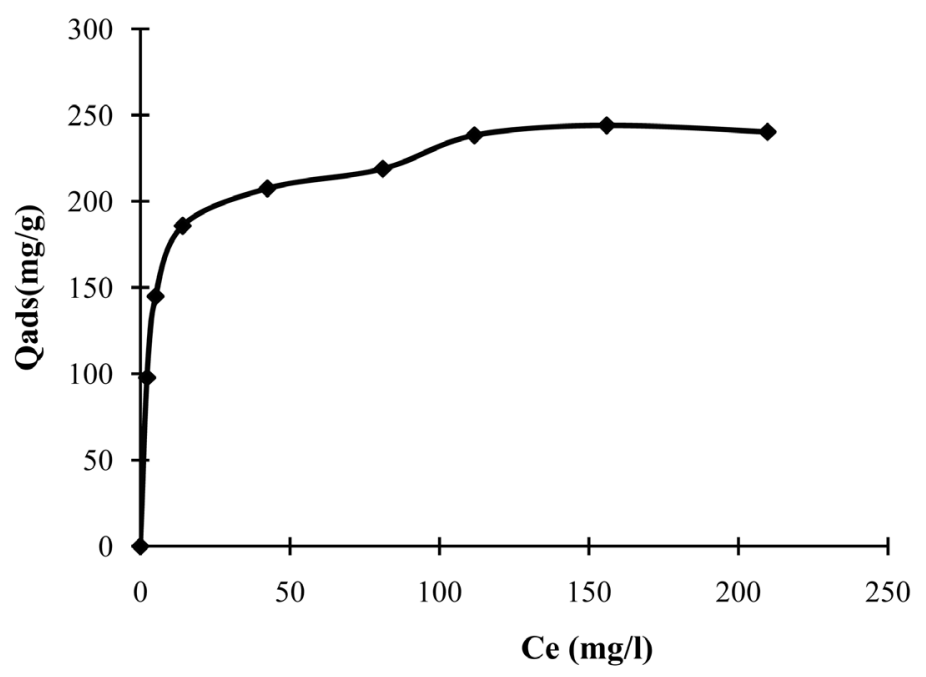

Figure 11. Adsorption isotherm of nitrates ions. 


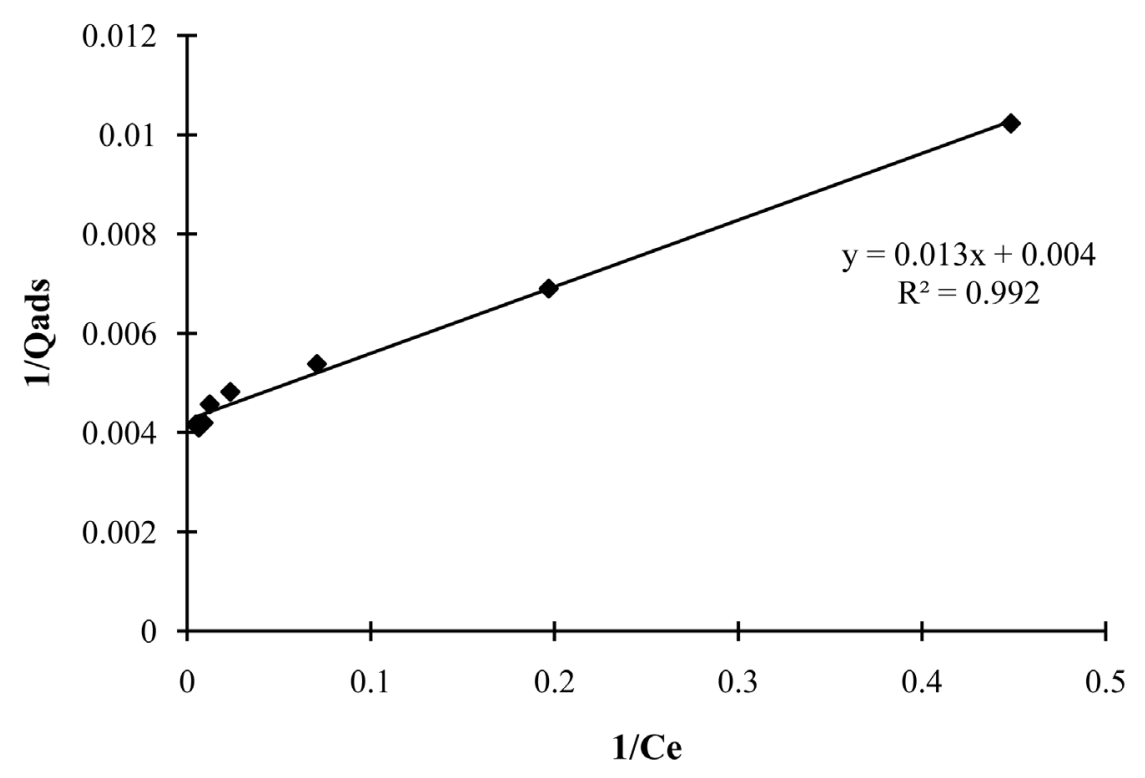

Figure 12. Langmuir isotherm linear plots for the adsorption of nitrates ions.

Table 4. Langmuir and Freundlich isotherm parameters.

\begin{tabular}{cccccccc}
\hline & \multicolumn{4}{c}{ Langmuir parameters } & \multicolumn{3}{c}{ Freundlich parameters } \\
\cline { 2 - 8 } $\begin{array}{c}Q_{\mathrm{m}, \text { exp }} \\
(\mathrm{mg} / \mathrm{g})\end{array}$ & $\begin{array}{c}Q_{\mathrm{m}, \mathrm{cal}} \\
(\mathrm{mg} / \mathrm{g})\end{array}$ & $\begin{array}{c}K_{L} \\
(1 / \mathrm{mg})\end{array}$ & $R^{2}$ & $R_{L}$ & $\begin{array}{c}K_{F} \\
((\mathrm{mg} / \mathrm{g})(1 / \mathrm{mg}) 1 / \mathrm{n})\end{array}$ & $1 / n$ & $R^{2}$ \\
\hline 244.06 & 250 & 0.307 & 0.992 & $7.186 \times 10^{-3} \leq R_{L} \leq 0.031$ & 99.683 & 0.181 & 0.908 \\
\hline
\end{tabular}

$\left(R_{L}=0\right)$, favorable $\left(0<R_{L}<1\right)$, linear $\left(R_{L}=1\right)$, or unfavorable $\left(R_{L}>1\right) . R_{L}$ values are well within the defined range (Table 4$)$ and indicate that the adsorption process is favorable.

\subsubsection{Freundlich Isotherm}

The Freundlich isotherm was proposed as the earliest empirical equation and was shown to be consistent with exponential distribution of active centers, characteristic of heterogeneous surfaces [38]. This model states that reactions take place in several sorption sites and as the amount of solute adsorbed rises, the binding surface energy decreases exponentially which means multilayer sorption [39]. The isotherm is expressed by the following equation:

$$
Q_{e}=K_{f} \cdot C_{e}^{1 / n}
$$

Logarithmic form of Equation (8) can be written as Equation (9):

$$
\ln Q_{e}=\ln K_{f}+(1 / n) \cdot \ln C_{e}
$$

where $K_{f}((\mathrm{mg} / \mathrm{g})(1 / \mathrm{mg}) 1 / n)$ and $n$ are Freundlich adsorption isotherm constants, the values of $K_{f}$ and $1 / n$ are determined from the intercept and slope of the linear regressions and are presented in Table 4. A plot of $\ln \left(Q_{e}\right)$ versus $\ln \left(C_{e}\right)$ for the studied samples is shown in Figure 13. The value $1 / n$ gives an indication on the validity of the adsorption of adsorbent-adsorbate system. A value 1/n between 0 and 1 that indicates a favorable adsorption [40]. In addition to that, this also indicates that the adsorption capacity increases, and further, adsorption sites appear. When $1 / n>1$, the adsorption is not favorable, the adsorption connections become weak and the adsorption capacity decreases. The values of $1 / n$ were less than one (Table 4 ) revealed favorable adsorption conditions. The correlation coefficient value is lower than Langmuir value. Therefore, adsorption does not follow Freundlich isotherm. Theoretical correlation of the experimental equilibrium adsorption data for the nitrate-clay system was properly explained by the Langmuir isotherm model. 


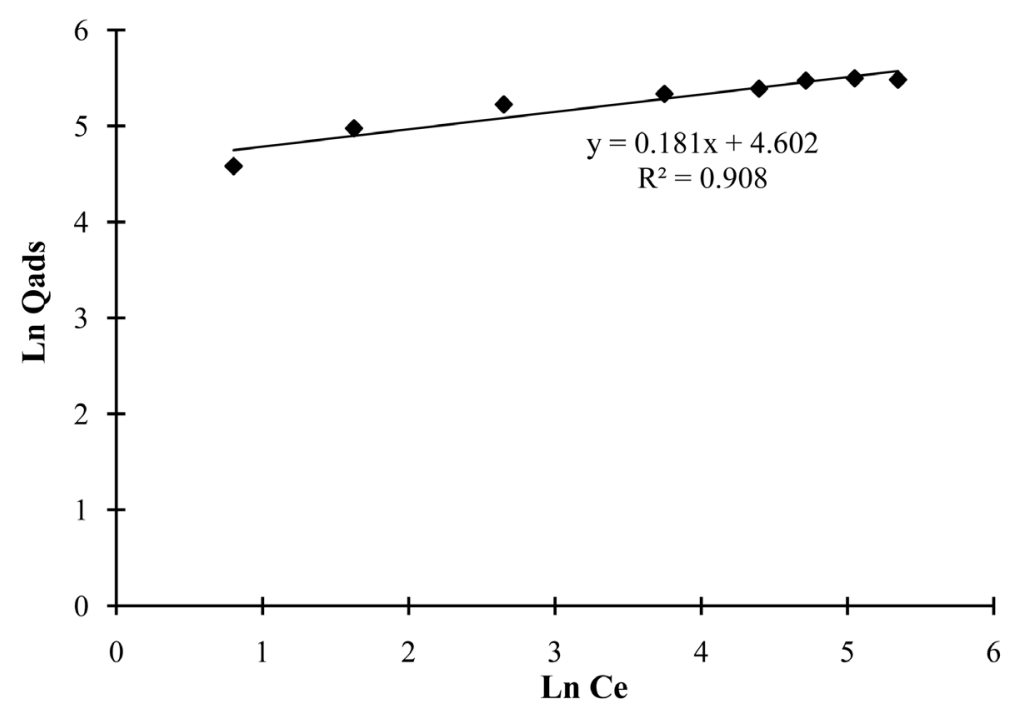

Figure 13. Freundlich isotherm linear plots for the adsorption of nitrates ions.

\section{Conclusion}

This study investigated the adsorption characteristics and suitability of our new natural clay mineral (NC) as potential adsorbent for the removal of nitrate from aqueous solutions using batch technique. The results showed that this clay could be used as potential sorbent and it was highly effective as low-cost adsorbent for the removal of nitrates ions from aqueous solutions. The batch study parameters, $\mathrm{pH}$ of solution, mass of adsorbent, initial solution concentration and contact time were found to be effective on the adsorption processes. The adsorption equilibrium was attained within $3 \mathrm{hrs}$. From the studies conducted, it was established that pseudo-first-order kinetic model described the kinetic rate. The percentage removal was found to decrease with increase in $\mathrm{pH}$. The increase in adsorbent dosage increased the percent removal of nitrate due to the increase in adsorbent surface area in adsorbent dosage. The equilibrium data fitted well the Langmuir isotherm equation and this adsorbent showed large uptake capacity of nitrate $\left(Q_{\mathrm{m} \text {, cal }}=250 \mathrm{mg} / \mathrm{g}, Q_{\mathrm{m} \text {, exp }}=244.06 \mathrm{mg} / \mathrm{g}\right)$. Our clay was a potential candidate as a highly efficient adsorbent for remediation of nitrate contaminated water owing to its exceptional uptake capacity as well as high selectivity for this anionic contaminant.

\section{References}

[1] Jeong, J.Y., Kim, H.K., Kim, J.H. and Park, J.Y. (2012) Electrochemical Removal of Nitrate Using ZVI Packed Bed Bipolar Electrolytic Cell. Chemosphere, 89, 172-178. http://dx.doi.org/10.1016/j.chemosphere.2012.05.104

[2] Zhou, M., Fu, W., Gu, H. and Lei, L. (2007) Nitrate Removal from Groundwater by a Novel Three-Dimensional Electrode Biofilm Reactor. Electrochimica Acta, 52, 6052-6059. http://dx.doi.org/10.1016/j.electacta.2007.03.064

[3] Thomson, T.S. (2001) Nitrate Concentration in Private Rural Drinking Water Supplies in Saskatchewan Canada. Bulletin of Environmental Contamination and Toxicology, 66, 64-70. http://dx.doi.org/10.1007/s001280000206

[4] Majumdar, D. and Gupta, N. (2000) Nitrate Pollution of Groundwater and Associated Human Health Disorders. Indian Journal of Environmental Health, 42, 28-39.

[5] Tate, C.H. and Arnold, K.F. (1990) Health and Aesthetic Aspects of Water Quality. In: Pontius, F.W., Ed., Water Quality and Treatment, McGraw-Hill Inc., New York, 63-156.

[6] Zheng, Y. and Wang, A. (2010) Nitrate Adsorption Using Poly(dimethyl diallyl ammonium chloride)/polyacrylamide hydrogel. Journal of Chemical \& Engineering Data, 55, 3494-3500. http://dx.doi.org/10.1021/je100169r

[7] Chatterjee, S. and Woo, S.H. (2009) The Removal of Nitrate from Aqueous Solutions by Chitosan Hydrogel Beads. Journal of Hazardous Materials, 164, 1012-1018. http://dx.doi.org/10.1016/j.jhazmat.2008.09.001

[8] Romano, N. and Zeng, C. (2009) Evaluating the Newly Proposed Protocol of Incorporated Potassium in Nitrate Toxicity Experiments at Different Salinities: A Case Study with the Tiger Prawn, Penaeus monodon, Juveniles. Aquaculture, 289, 304-309. http://dx.doi.org/10.1016/j.aquaculture.2009.01.035

[9] Ward, M.H., de Kok, T.M., Levallois, P., Brender, J., Gulis, G., Nolan, B.T. and Van Derslice, J. (2005) Workgroup 
Report: Drinking-Water Nitrate and Health Recent Findings and Research Needs. Environmental Health Perspectives, 113, 1607-1614. http://dx.doi.org/10.1289/ehp.8043

[10] Lin, S.H. and Wu, C.L. (1996) Removal of Nitrogenous Compounds from Aqueous Solution by Ozonation and Ion Exchange. Water Research, 30, 1851-1857. http://dx.doi.org/10.1016/0043-1354(95)00329-0

[11] Kostraba, T.N., Gay, E.C., Rewers, M. and Hamman, R.F. (1992) Nitrate Levels in Community Drinking Waters and Risk of IDDM, An Ecological Analysis. Diabetes Care, 15, 1505-1508. http://dx.doi.org/10.2337/diacare.15.11.1505

[12] Wolfe, A.H. and Patz, J.A. (2002) Reactive Nitrogen and Human Health: Acute and Long-Term Implications. AMBIO: A Journal of the Human Environment, 31, 120-125. http://dx.doi.org/10.1579/0044-7447-31.2.120

[13] US Environmental Protection Agency (2000) Drinking Water Standards and Health 614 Advisories. US Environmental Protection Agency, Office of Water, Washington DC, 822-B-00-001.

[14] Schipper, L.A. and Vukovic, M.V. (2001) Five Years of Nitrate Removal, Denitrification and Carbon Dynamics in a Denitrification Wall. Water Research, 35, 3473-3477. http://dx.doi.org/10.1016/S0043-1354(01)00052-5

[15] Hu, H.Y., Goto, N. and Fujie, K. (2001) Effect of pH on the Reduction of Nitrite in Water by Metallic Iron. Water Research, 35, 2789-2793. http://dx.doi.org/10.1016/S0043-1354(00)00570-4

[16] Pinter, A. and Batista, J. (2006) Improvement of an Integrated Ion-Exchange/Catalytic Process for Nitrate Removal by Introducing a Two-Stage Denitrification Step. Applied Catalysis B: Environmental, 63, 150-159. http://dx.doi.org/10.1016/j.apcatb.2005.10.006

[17] Baes, B.U., Jung, Y.H., Han, W.W. and Shin, H.S. (2002) Improved Brine Recycling during Nitrate Removal Using Ion Exchange. Water Research, 36, 3330-3340. http://dx.doi.org/10.1016/S0043-1354(02)00012-X

[18] Churchman, G.J., Gates, W.P., Theng, B.K.G. and Yuan, G. (2006) Clays and Clay Minerals for Pollution Control Handbook of Clay Science. Developments in Clay Science, 1, 625-675.

[19] El ouardi, M., Qourzal, S., Alahiane, S., Sakr, F., Assabbane, A. and Douch, J. (2014) Agadir Clay Materials as a New Adsorbent to Remove Cationic and Anionic Dyes from Aqueous Solutions. International Journal of Scientific Research and Thesis, 3, 72-87.

[20] Robinson, J.W. and Hsu, C.J. (1969) Spectroscopic Studies of the Chromotropic Acid-Nitrate Reaction. Analytica Chimica Acta, 44, 51-58. http://dx.doi.org/10.1016/S0003-2670(01)81736-0

[21] West, P.W. and Lyles, G.L. (1960) A New Method for the Determination of Nitrates. Analytica Chimica Acta, 23, 227232. http://dx.doi.org/10.1016/S0003-2670(60)80057-8

[22] Vieira, A.P., Santana, S.A.A., Bezerra, C.W.B., Silva, H.A.S., Chaves, J.A.P., de Melo, J.C.P., da Silva Filho, E.C. and Airoldi, C. (2009) Kinetics and Thermodynamics of Textile Dye Adsorption from Aqueous Solutions Using Babassu Coconut Mesocarp. Journal of Hazardous Materials, 166, 1272-1278. http://dx.doi.org/10.1016/j.jhazmat.2008.12.043

[23] Njoya, A., Nkoumbou, C., Grosbois, C., Njopwouo, D., Njoya, D. and Courtin-Nkoumbou, A. (2006) Genesis of Mayouom Kaolin Deposit (Western Cameroun). Applied Clay Science, 32, 125-140. http://dx.doi.org/10.1016/j.clay.2005.11.005

[24] Dawodu, F.A. and Akpomie, K.G. (2014) Simultaneous Adsorption of Ni(II) and Mn(II) Ions from Aqueous Solution unto a Nigerian Kaolinite Clay. Journal of Materials Research and Technology, 3, 129-141.

[25] Bhattacharrya, G. and Gupta, S.S. (2006) Pb(II) Uptake by Kaolinite and Montmorillonite in Aqueous Medium: Influence of Acid Activation of the Clays. Colloids and Surfaces A, 277, 191-200. http://dx.doi.org/10.1016/j.colsurfa.2005.11.060

[26] Guo, X.L., Zengle, L. and Park, X.S. (2008) Ammonium and Potassium Anaerobically Removal for Digested Wastewater Using Natural Clinoptilolite Followed by Membrane Pretreatment. Journal of Hazardous Materials, 151, 125133. http://dx.doi.org/10.1016/j.jhazmat.2007.05.066

[27] Bagherifam, S., Lakzian, A., Ahmadi, S., Rahimi, F. and Halajnia, A. (2010) Uranium Removal from Aqueous Solutions by Wood Powder and Wheat Straw. Journal of Radioanalytical and Nuclear Chemistry, 283, 289-296. http://dx.doi.org/10.1007/s10967-009-0348-4

[28] Elmoubarki, R., Mahjoubi, F.Z., Tounsadi, H., Moustadraf, J., Abdennouri, M., Zouhri, A., ElAlbani, A. and Barka, N. (2015) Adsorption of Textile Dyes on Raw and Decanted Moroccan Clays: Kinetics, Equilibrium and Thermodynamics. Water Resources and Industry, 9, 16-29. http://dx.doi.org/10.1016/j.wri.2014.11.001

[29] Tahir, H. (2005) Comparative Trace Metal Contents in Sediments and Liquid Waste from Tanneries and Their Removal of Chromium Using Zeolite 5A. Electronic Journal of Environmental, Agricultural and Food Chemistry, 4, 23-29.

[30] Moussavi, G. and Khosravi, R. (2011) The Removal of Cationic Dyes from Aqueous Solutions by Adsorption onto Pistachio Hull Waste. Chemical Engineering Research and Design, 89, 2182-2189. http://dx.doi.org/10.1016/j.cherd.2010.11.024

[31] Vimonses, V., Lei, S., Jin, B., Chow, C.W.K. and Saint, C. (2009) Adsorption of Congo Red by Three Australian Kao- 
lins. Applied Clay Science, 43, 465-472. http://dx.doi.org/10.1016/j.clay.2008.11.008

[32] Islam, M. and Patel, R. (2011) Physicochemical Characterization and Adsorption Behavior of Ca/Al Chloride Hydrotalcite-Like Compound towards Removal of Nitrate. Journal of Hazardous Materials, 190, 659-668. http://dx.doi.org/10.1016/j.jhazmat.2011.03.094

[33] Wang, Y., Gao, B.Y., Yue, W.W. and Yue, Q.Y. (2007) Adsorption Kinetics of Nitrate from Aqueous Solutions onto Modified Wheat Residue. Colloids and Surfaces A, 308, 1-5. http://dx.doi.org/10.1016/j.colsurfa.2007.05.014

[34] Han, X., Wang, W. and Ma, X. (2011) Adsorption Characteristics of Methylene Blue onto Low Cost Biomass Material Lotus Leaf. Chemical Engineering Journal, 171, 1-8. http://dx.doi.org/10.1016/j.cej.2011.02.067

[35] Hoda, N., Bayram, E. and Ayranci, E. (2006) Kinetic and Equilibrium Studies on the Removal of Acid Dyes from Aqueous Solutions by Adsorption onto Activated Carbon Cloth. Journal of Hazardous Materials, 137, 344-351. http://dx.doi.org/10.1016/j.jhazmat.2006.02.009

[36] Mohan, D. and Chander, S. (2006) Single, Binary, and Multicomponent Sorption of Iron and Manganese on Lignite. Journal of Colloid and Interface Science, 299, 76-87. http://dx.doi.org/10.1016/j.jcis.2006.02.010

[37] Seliem, M.K., Komarneni, S., Byrne, T., Cannon, F.S., Shahien, M.G., Khalil, A.A. and Abd El-Gaid, I.M. (2013) Removal of Nitrate by Synthetic Organosilicas and Organoclay: Kinetic and Isotherm Studies. Separation and Purification Technology, 110, 181-187. http://dx.doi.org/10.1016/j.seppur.2013.03.023

[38] Gammoudi, S., Srasra, N.F. and Srasra, E. (2012) Nitrate Sorption by Organosmectites. Engineering Geology, 124, 119-129. http://dx.doi.org/10.1016/j.enggeo.2011.10.009

[39] Yusan, S. and Akyil, S. (2008) Sorption of Uranium (VI) from Aqueous Solutions by Akaganeite. Journal of Hazardous Materials, 160, 388-395. http://dx.doi.org/10.1016/j.jhazmat.2008.03.009

[40] Tsai, W.T., Chang, Y.M., Lai, C.W. and Lo, C.C. (2005) Adsorption of Basic Dyes in Aqueous Solution by Clay Adsorbent from Regenerated Bleaching Earth. Applied Clay Science, 29, 149-154.

http://dx.doi.org/10.1016/j.clay.2004.10.004 